\title{
Audit Opinion and Financial Performance of Local Governments in East Nusa Tenggara
}

\author{
Jennie S. Sir*, Selfesina Samadara, Deetje W. Manuain \\ Kupang State Polytechnic \\ Kupang, Indonesia \\ *jenniesir678@gmail.com, selfisamadara@gmail.com,d3c3_manuain@yahoo.com
}

\begin{abstract}
This study aims to analyze the effect of audit opinion on the financial performance of local governments by using data from 22 districts / cities in East Nusa Tenggara (NTT) during 2015-2019. This study examines the effect of the previous year's audit opinion on the financial performance of the Regional Government (district / city), mediated by the realization of Original Local Government Revenue (PAD) and the realization of Regional Operational Expenditures. The results of this study indicate that the audit opinion has a significant effect on the financial performance of local governments, and significant effect on the realization of $\mathrm{PAD}$ and the realization of operational spending. This study are also recommended for the Regional Government in East Nusa Tenggara, the Inspectorate at the Provincial and Regency levels, and the Supreme Audit Agency (BPK), in determining policies, monitoring and auditing in order to improve the financial performance of Regional Governments in East Nusa Tenggara.
\end{abstract}

Keywords-audit opinion, financial performance, local government

\section{INTRODUCTION}

With the existence of Government Regulation 71/2010 concerning Governmental Accounting Standards, there has been a change in financial reporting from Cash Toward Accrual (CTA) -based Financial Statements to Accrual-based Financial Statements, the number of Financial Reports presented has changed from 3 reports to 7 reports, namely Budget Realization Reports, Changes in Excess Budget Balance, Balance Sheet, Operational Report, Cash Flow Statement and Change in Equity Report and Notes to Financial Statements, attached with Regional Company Financial Statements [1].

At the end of each period, the Regional Heads, be it the Governor / Regent / Mayor convey the accountability for the implementation of the APBD to DPRD in the form of financial reports that have been audited by the Supreme Audit Agency (BPK) no later than 6 (six) months after the end of the fiscal year. One of the concrete efforts to achieve transparency and accountability in the management of state finances is the submission of government financial accountability reports that comply with the principles on time and are prepared in accordance with generally accepted government accounting standards.

The Regional Government Financial Reports need to be audited by the Supreme Audit Agency (BPK) in an effort to improve the quality of transparency and accountability. The examiner (BPK) prepares an Audit Result Report (LHP) after the examination has been completed. Article 16 paragraph (1) of Law number 15 of 2004 states that the audit report on government financial reports contains an opinion. Opinion is a professional statement as a conclusion from the examiner regarding the fairness level of the information presented in the financial statements [2].

East Nusa Tenggara Province as a region that has 22 Regencies / Cities must be audited annually to assess the financial performance of the Regional Government in each of these Regencies / Cities. Based on data obtained from the BPK RI Representative Office for East Nusa Tenggara Province, for 4 consecutive years, since 2015, the NTT Provincial government has annually received Unqualified Opinions (WTP). However, at the Regency / City level, there are still many who get a Qualified Opinion (WDP) and some even get a Disclaimer opinion.

Based on the results of the examination of the Regional Government Financial Statements (LKPD) as outlined in the Press Release issued by the BPK RI Representative of the Province of NTT, it was explained that in 2015, only 1 Regency in NTT Province received a WTP opinion, namely East Sumba Regency, while 19 Regencies / Cities received WDP opinion, and 2 Districts get a Disclaimer opinion. In 2016, only 2 districts in NTT Province received WTP opinions, namely East Sumba and Sikka districts, while 20 districts / cities received WDP opinions. In 2017, only 1 district in NTT Province received a WTP opinion, namely Sikka Regency, while 21 other districts / cities received a WDP opinion. Meanwhile, in 2018, there were 7 districts in the NTT Province that received WTP opinions and 15 districts / cities obtained WDP opinions (Fair with Exceptions). In 2019, there were 11 districts / cities in NTT that received a WTP opinion, while 11 other districts received a WDP opinion.

Based on this description, it is very important to conduct a study on the performance of the Regional Government after 
giving an audit opinion, to find out whether there is a significant impact between the provision of an audit opinion and the performance of the Regional Government. This study refer to previous research more comprehensively on the study of the characteristics of the NTT local government and the effectiveness of the role of the internal auditor [3]. So that this study aims to provide empirical evidence on the direct effect of audit opinion on the performance of local governments, and also aims to analyze the indirect effect of audit opinion on local government performance by considering the level of achievement of local revenue realization and regional operational expenditure as mediation by examining the characteristics of local government. And the role of the internal auditor.

\section{METHODS}

This study uses quantitative data analysis methods. The data source of this research is secondary data, which includes: BPK Audit Result Report (LHP) data on LKPD obtained from BPK, evaluation data on the implementation of the Government Agency Performance Accountability System (SAKIP) through Government Agency Performance Report (LAKIP) obtained from Provincial BAPPEDA as well as from each district in NTT, budget data and regional revenue and expenditure realization are obtained from the directory of the Ministry of Finance.

The observation period in this study is for 4 years, namely 2015 to 2019, both for the sample of all districts / cities in East Nusa Tenggara Province, which in total are 22 districts / cities. For BPK Audit Result Report (LHP) data from 2015 to 2018, while data on the Government Agency Performance Accountability System (SAKIP) or Government Agency Performance Report (LAKIP), as well as budget data and the realization of revenue and expenditure observed from 2016 to with 2019. The sample criteria used in this study are samples that have complete data related to all the variables studied, namely having audit opinion data, performance evaluation, financial report data in the form of realized regional income and expenditure.

To analyze the effect of giving audit opinion on local government performance, the empirical model uses multiple linear regression testing as follows:

$$
\text { PERFORMit }=\beta 0+\beta 1 \text { OPINIit } 1+\beta 2 \text { PADit }+\beta 3 \text { BELit }+\varepsilon
$$

Where the PERFORMANCE as an endogenous variable in this study is the Performance of Local Government, which is measured by the score of the results of the evaluation of the Government Agency Performance Accountability System (SAKIP) year t. As regulated in the Regulation of the Minister for Administrative Reform and Bureaucratic Reform No. 20 of 2013 [4]. Concerning the Amendment to the Appendix to the Regulation of the Minister for Administrative Reform and Bureaucratic Reform No. 25 of 2012 [5]. Regarding the
Implementation Guidelines for Performance Accountability Evaluation of Government Agencies, there are five components in the evaluation of the implementation of SAKIP, namely (i). Performance planning (weight 35 percent); (ii). Performance measurement (weight 20 percent); (iii). Performance reporting (weight 15 percent); (iv). Internal evaluation (weight 10 percent); and (v). Performance Achievements (weighted 20 percent). The evaluation of items $i$ to iv is related to the implementation of SAKIP in government agencies, while point $\mathrm{v}$ is related to the achievement of performance, both as stated in the performance report document (LAKIP) or in other documents. The scores generated on the results of the evaluation of SAKIP implementation are in the range of $0-100$, with the following categories: (i). $\mathrm{AA}=>85-100 /$ satisfactory; (ii). $\mathrm{A}=>75-85$ / very good; (iii). $\mathrm{B}=>65-75 /$ good; (iv). $\mathrm{CC}$ => 50-65/ enough; (v). $C=>30-50 /$ less; and (vi). $\mathrm{D}=>0-30 /$ very less.

OPINION is an audit opinion determined by the BPK based on the results of the examination of the previous year's LKPD $(\mathrm{t}-1)$, which is measured categorically, namely "5" for Unqualified opinion (WTP), "4" for Unqualified opinion with Explanatory Paragraph (WTP-DPP), "3" for an unqualified opinion (WDP), "2" for an Unfair opinion (TW), and "1" for a disclaimer

Stipulation of opinion by BPK as stipulated in Law Number 15 Year 2004 regarding State Financial Management and Responsibility Audit is based on the following criteria: (1) Conformity with Government Accounting Standards (SAP); (2) Adequate disclosures; (3). Compliance with laws and regulations, and (4). Effectiveness of Government Internal Control System (SPIP).

PAD is the amount of Original Local Government Revenue, which is measured using two approaches, namely (i) the natural logarithm of the absolute value of the total Original Local Government Revenue in year t; and (ii) percentage of Original Local Government Revenue compared to total regional revenue in year t. As regulated in Government Regulation Number 71 of 2010 concerning Government Accounting Standards, which is included in the category of Original Local Government Revenue for Provincial Governments, is regional tax revenue, regional retribution income, revenue from the management of separated regional assets and other legal PAD.

BEL is the amount of regional operational expenditure, which is measured using two approaches, namely (i) the natural logarithm of the absolute value of the total regional expenditure in year t; and (ii) percentage of regional operating expenditure compared to total regional expenditure in year t. As stipulated in Government Regulation Number 71 of 2010 concerning Government Accounting Standards, which is included in the category of Regional operating expenditures for Regional Governments, is personnel expenditure, goods and services expenditure, interest, subsidies, grants and social assistance. 


\section{RESULTS AND DISCUSSION}

\section{A. Analysis of Local Government Revenue and Expenditure in} NTT

1) Analysis financial autonomy of local governments: shows the capacity of local governments in self-finance government activities, development and services to people who have paid taxes and levies as a source of income required area. Regional financial independence is shown by a comparison between local revenue (PAD) with total revenue. The following table 1 shows the analysis Financial Autonomy of Local Governments:

TABLE I. ANALYSIS FINANCIAL AUTONOMY OF LOCAL GOVERNMENTS

\begin{tabular}{|l|l|l|l|l|l|}
\hline \multirow{2}{*}{ No } & \multirow{2}{*}{ District / City } & \multicolumn{4}{|c|}{ Year } \\
\cline { 3 - 6 } & & $\begin{array}{c}\mathbf{2 0 1 6} \\
(\%)\end{array}$ & $\begin{array}{c}\mathbf{2 0 1 7} \\
(\boldsymbol{\%})\end{array}$ & $\begin{array}{c}\mathbf{2 0 1 8} \\
(\boldsymbol{\%})\end{array}$ & $\begin{array}{c}\mathbf{2 0 1 9} \\
(\boldsymbol{\%})\end{array}$ \\
\hline 1 & Alor & 4.80 & 7.72 & 5.64 & 4.52 \\
\hline 2 & Belu & 9.16 & 10.55 & 9.57 & 8.89 \\
\hline 3 & Ende & 5.96 & 8.63 & 5.58 & 5.57 \\
\hline 4 & East Flores & 4.74 & 5.36 & 5.11 & 5.47 \\
\hline 5 & Kupang & 6.26 & 10.44 & 5.35 & 4.90 \\
\hline 6 & Lembata & 4.83 & 5.19 & 5.40 & 5.67 \\
\hline 7 & Manggarai & 7.33 & 11.59 & 8.19 & 8.43 \\
\hline 8 & Ngada & 6.04 & 7.57 & 5.43 & 6.11 \\
\hline 9 & Sikka & 7.53 & 11.35 & 9.01 & 8.04 \\
\hline 10 & West Sumba & 8.90 & 12.31 & 10.54 & 10.23 \\
\hline 11 & East Sumba & 6.36 & 8.83 & 6.93 & 8.21 \\
\hline 12 & $\begin{array}{l}\text { South Central } \\
\text { Timor }\end{array}$ & 5.98 & 13.36 & 4.91 & 5.16 \\
\hline 13 & $\begin{array}{l}\text { North Central } \\
\text { Timor }\end{array}$ & 5.22 & 7.70 & 5.32 & 5.20 \\
\hline 14 & Kupang City & 14.50 & 19.82 & 14.66 & 15.89 \\
\hline 15 & Rote Ndao & 4.07 & 6.63 & 3.58 & 3.87 \\
\hline 16 & West Manggarai & 10.32 & 12.16 & 9.82 & 14.60 \\
\hline 17 & Nagekeo & 4.11 & 6.08 & 4.43 & 3.92 \\
\hline 18 & Central Sumba & 4.09 & 10.52 & 4.40 & 4.55 \\
\hline 19 & $\begin{array}{l}\text { South } \\
\text { Sumba }\end{array}$ & 5.19 & 5.47 & 5.13 & 4.90 \\
\hline 20 & East Manggarai & 5.11 & 9.36 & 4.29 & 4.88 \\
\hline 21 & Sabu Raijua & 5.64 & 8.90 & 5.53 & 5.10 \\
\hline 22 & Malaka & 4.44 & 6.65 & 5.45 & 5.85 \\
\hline
\end{tabular}

The results of the analysis show that the level of financial Autonomy of local governments in NTT is still low.

2) Analysis of revenue effectiveness and spending efficiency: The revenue-effectiveness analysis illustrates the ability of local governments to do this PAD planned with the PAD target set. Meanwhile, the expenditure efficiency analysis is a comparison between the expenditure realization and the expenditure budget. The expenditure efficiency analysis is used to measure the level of budget savings made by local governments.

The following table 2 shows the analysis Revenue Effectiveness of Local Governments:

TABLE II. ANALYSIS REVENUE EFFECTIVENESS OF LOCAL GOVERNMENTS

\begin{tabular}{|c|c|c|c|c|c|}
\hline \multirow[t]{2}{*}{ No } & \multirow{2}{*}{$\begin{array}{l}\text { District / } \\
\text { City }\end{array}$} & \multicolumn{4}{|c|}{ Year } \\
\hline & & $\begin{array}{l}2016 \\
(\%)\end{array}$ & $\begin{array}{l}2017 \\
(\%)\end{array}$ & $\begin{array}{c}2018 \\
(\%)\end{array}$ & $\begin{array}{l}2019 \\
(\%)\end{array}$ \\
\hline 1 & Alor & 101.69 & 156.48 & 109.30 & 84.31 \\
\hline 2 & Belu & 120.00 & 171.79 & 129.47 & 106.72 \\
\hline 3 & Ende & 110.19 & 161.58 & 76.91 & 87.60 \\
\hline 4 & East Flores & 85.77 & 108.16 & 93.76 & 83.36 \\
\hline 5 & Kupang & 75.54 & 117.96 & 66.23 & 85.39 \\
\hline 6 & Lembata & 117.96 & 123.79 & 116.85 & 69.72 \\
\hline 7 & Manggarai & 94.44 & 133.88 & 91.57 & 106.33 \\
\hline 8 & Ngada & 142.64 & 137.84 & 88.02 & 100.30 \\
\hline 9 & Sikka & 85.39 & 103.50 & 96.68 & 95.52 \\
\hline 10 & $\begin{array}{l}\text { West } \\
\text { Sumba }\end{array}$ & 115.61 & 149.60 & 104.20 & 80.84 \\
\hline 11 & $\begin{array}{l}\text { East } \\
\text { Sumba }\end{array}$ & 95.32 & 112.59 & 77.15 & 103.63 \\
\hline 12 & $\begin{array}{l}\text { South } \\
\text { Central } \\
\text { Timor }\end{array}$ & 99.88 & 273.06 & 82.73 & 84.23 \\
\hline 13 & $\begin{array}{l}\text { North } \\
\text { Central } \\
\text { Timor }\end{array}$ & 113.97 & 183.80 & 85.31 & 95.71 \\
\hline 14 & $\begin{array}{l}\text { Kupang } \\
\text { City }\end{array}$ & 117.32 & 142.46 & 98.00 & 99.18 \\
\hline 15 & Rote Ndao & 100.94 & 164.65 & 108.42 & 111.67 \\
\hline 16 & $\begin{array}{l}\text { West } \\
\text { Manggarai }\end{array}$ & 119.65 & 125.95 & 85.81 & 102.77 \\
\hline 17 & Nagekeo & 105.47 & 156.46 & 110.41 & 100.80 \\
\hline 18 & $\begin{array}{l}\text { Central } \\
\text { Sumba }\end{array}$ & 100.05 & 242.54 & 95.65 & 110.70 \\
\hline 19 & $\begin{array}{l}\text { South West } \\
\text { Sumba }\end{array}$ & 112.68 & 123.11 & 104.23 & 111.54 \\
\hline 20 & $\begin{array}{l}\text { East } \\
\text { Manggarai }\end{array}$ & 133.10 & 179.70 & 86.70 & 88.40 \\
\hline 21 & $\begin{array}{l}\text { Sabu } \\
\text { Raijua } \\
\end{array}$ & 62.69 & 68.62 & 47.16 & 39.93 \\
\hline 22 & Malaka & 125.03 & 200.78 & 104.94 & 96.13 \\
\hline
\end{tabular}

The results of the analysis show that the level of realization of PAD in local governments in NTT has been effective. Meanwhile, expenditure realization is still inefficient (See Table 3). 
TABLE III. ANALYSIS OF SPENDING EFFICIENCY

\begin{tabular}{|c|c|c|c|c|c|}
\hline \multirow[t]{2}{*}{ No } & \multirow{2}{*}{$\begin{array}{c}\text { District / } \\
\text { City }\end{array}$} & \multicolumn{4}{|c|}{ Year } \\
\hline & & $\begin{array}{c}2016 \\
(\%)\end{array}$ & $\begin{array}{c}2017 \\
(\%)\end{array}$ & $\begin{array}{c}2018 \\
(\%)\end{array}$ & $\begin{array}{l}2019 \\
(\%)\end{array}$ \\
\hline 1 & Alor & 94.25 & 103.73 & 99.86 & 95.86 \\
\hline 2 & Belu & 91.18 & 100.13 & 100.20 & 98.19 \\
\hline 3 & Ende & 84.22 & 98.99 & 96.15 & 96.47 \\
\hline 4 & East Flores & 98.16 & 99.32 & 97.46 & 98.99 \\
\hline 5 & Kupang & 91.91 & 95.83 & 87.22 & 88.03 \\
\hline 6 & Lembata & 88.39 & 89.86 & 96.92 & 95.83 \\
\hline 7 & Manggarai & 97.21 & 93.63 & 97.15 & 97.52 \\
\hline 8 & Ngada & 95.89 & 99.72 & 92.18 & 96.13 \\
\hline 9 & Sikka & 92.81 & 88.59 & 93.22 & 95.82 \\
\hline 10 & $\begin{array}{l}\text { West } \\
\text { Sumba }\end{array}$ & 99.93 & 102.24 & 97.60 & 96.48 \\
\hline 11 & East Sumba & 90.01 & 95.02 & 95.12 & 93.49 \\
\hline 12 & $\begin{array}{l}\text { South } \\
\text { Central } \\
\text { Timor }\end{array}$ & 91.43 & 92.39 & 98.44 & 94.90 \\
\hline 13 & $\begin{array}{l}\text { North } \\
\text { Central } \\
\text { Timor }\end{array}$ & 95.72 & 91.52 & 89.59 & 87.91 \\
\hline 14 & $\begin{array}{l}\text { Kupang } \\
\text { City }\end{array}$ & 99.75 & 105.44 & 96.99 & 96.57 \\
\hline 15 & Rote Ndao & 98.63 & 100.27 & 98.59 & 99.88 \\
\hline 16 & $\begin{array}{l}\text { West } \\
\text { Manggarai }\end{array}$ & 100.59 & 97.55 & 93.64 & 94.36 \\
\hline 17 & Nagekeo & 97.18 & 99.68 & 98.25 & 92.40 \\
\hline 18 & $\begin{array}{l}\text { Central } \\
\text { Sumba }\end{array}$ & 95.53 & 105.71 & 89.71 & 93.29 \\
\hline 19 & $\begin{array}{l}\text { South West } \\
\text { Sumba }\end{array}$ & 91.23 & 97.47 & 94.47 & 95.91 \\
\hline 20 & $\begin{array}{l}\text { East } \\
\text { Manggarai }\end{array}$ & 96.96 & 97.19 & 96.97 & 98.02 \\
\hline 21 & Sabu Raijua & 96.92 & 68.91 & 82.59 & 84.57 \\
\hline 22 & Malaka & 85.99 & 101.85 & 91.53 & 87.80 \\
\hline
\end{tabular}

\section{B. The Results of Variable Correlation Analysis}

The results of the correlation analysis between variables are presented in Table 4 . In Table 4 shows that except for the variable operating expenditure percentage (P_OPER), all variables in this study have a positive and significant correlation to the variable Local government performance, as well as for the audit opinion variable, has a strong correlation positive and significant towards the PAD variable both the absolute value (N_PAD) and percentage (P_PAD) and operating expenditure variables, in particular using absolute value measurement (N_OPER). This indicates that apart from correlation with local government financial performance, audit opinion also has a correlation with PAD and operation expenditure.
TABLE IV. The RESUlt OF THE CORRELATION ANALYSIS

\begin{tabular}{|l|l|l|l|l|l|l|}
\hline Variable & Perform & Opinion & P_PAD & Ln_PAD & $\begin{array}{c}\text { P_OP } \\
\text { ER }\end{array}$ & $\begin{array}{c}\text { Ln_O } \\
\text { PER }\end{array}$ \\
\hline Perform & 1.000 & & & & & \\
\hline Opinion & $\begin{array}{l}0.568^{* * *} \\
(0.000)\end{array}$ & 1.000 & & & & \\
\hline P_PAD & $\begin{array}{l}0.213^{* * *} \\
(0.000)\end{array}$ & $\begin{array}{l}0.617 * * * \\
(0.000)\end{array}$ & 1.000 & & & \\
\hline Ln_PAD & $\begin{array}{l}0.426^{* * *} \\
(0.000)\end{array}$ & $\begin{array}{l}0.549^{* * *} \\
(0.000)\end{array}$ & $\begin{array}{l}0.392^{* * *} \\
(0.000)\end{array}$ & 1.000 & & \\
\hline P_OPER & $\begin{array}{l}0.002 \\
(0.854)\end{array}$ & $\begin{array}{l}0.010 \\
(0.626)\end{array}$ & $\begin{array}{l}- \\
0.842^{* * *} \\
(0.000)\end{array}$ & $\begin{array}{l}0.514^{* * *} \\
(0.000)\end{array}$ & 1.000 & \\
\hline Ln_OPER & $\begin{array}{l}0.792^{* * *} \\
(0.000)\end{array}$ & $\begin{array}{l}0.583^{* *} \\
(0.014)\end{array}$ & $\begin{array}{l}0.289 * * * \\
(0.000)\end{array}$ & $\begin{array}{l}0.415^{* * *} \\
(0.000)\end{array}$ & $\begin{array}{l}0.068 \\
(0.360)\end{array}$ & 1.000 \\
\hline
\end{tabular}

\section{Hypothesis Testing Results}

The results of this study indicates that the model used to test the direct effect of audit opinion local government performance can explain variations in government performance is 20.15 percent and significant at the 1 percent level (in Table 5). On the test results this model shows that the audit opinion directly has a positive and significant effect to the performance of local governments with a coefficient of 5.079 at the level a significance of 1 percent. These results suggest that the data used on this research supports the hypothesis. This means that when there is an increase in audit opinion by 1 point then this can lead to an increase in the performance of the Regional Government by 5,079 points In addition, the results of this direct test also show that PAD and regional operating expenditures have a positive and significant effect on the performance of local governments with a coefficient of 0.327 and 0.617. The meaning when there is an increase in PAD of 1 percent it can lead to increased performance Local Government is 0.327 , meanwhile when there is an increase in operating spending area by 1 percent it can increase the performance of 0.617 .

For the test results the indirect effect of audit opinion on performance Provincial Government through the realization of PAD as in table 5 it is found that Audit opinion has a positive and significant effect on the realization of PAD with a coefficient amounting to 3,247. Meanwhile, based on the results of testing the mediating role of regional operational expenditure realization. It was found that the audit opinion did not have a significant effect on operation expenditure realization. These results are consistent with previous research [6]. 
TABLE V. HyPOTHESIS TESTING RESULTS

\begin{tabular}{|l|l|l|l|l|}
\hline Variable & Sign & \multicolumn{1}{|c|}{ Perform } & \multicolumn{1}{|c|}{ P_PAD } & P_OPER \\
\hline Intercept & & $\begin{array}{l}-17.681 \\
(0.259)\end{array}$ & $\begin{array}{l}-57.480^{* * *} \\
(0.009)\end{array}$ & $\begin{array}{l}257.396^{* * *} \\
(0.000)\end{array}$ \\
\hline Opinion & + & $\begin{array}{l}5.079^{* * *} \\
(0.000)\end{array}$ & $\begin{array}{l}3.247^{* *} \\
(0.015)\end{array}$ & - \\
\hline P_PAD & + & $\begin{array}{l}0.617^{* * *} \\
(0.006)\end{array}$ & - & - \\
\hline P_OPER & $+/-$ & $\begin{array}{l}0.327^{* *} \\
(0.012)\end{array}$ & - & - \\
\hline $\begin{array}{l}\text { Number of } \\
\text { observations }\end{array}$ & 88 & 88 & 88 & 88 \\
\hline $\begin{array}{l}\text { Adj. R } \\
\text { Squared }\end{array}$ & & - & 40.79 & $\begin{array}{l}5.30 \\
-\end{array}$ \\
\hline
\end{tabular}

\section{CONCLUSION}

This study aims to analyze the effect of audit opinion on the financial performance of local governments by using data from 22 districts / cities in the NTT province during 2015-2019. This study examines the effect of the previous year's audit opinion on the financial performance of the Regional Government (district / city), mediated by the realization of Original Local Government Revenue (PAD) and the realization of Regional Operational Expenditures. The results of this study indicate that the audit opinion has a significant effect on the financial performance of local governments, but has no significant effect on the realization of PAD and the realization of operational spending. The implications of this research can be used for the Regional Government in East Nusa Tenggara, the Inspectorate at the Provincial and Regency levels, and the BPK, in determining policies, monitoring and auditing in order to improve the financial performance of Regional Governments in East Nusa Tenggara.

\section{REFERENCES}

[1] Peraturan Pemerintah RI Nomor 71 tahun 2010 tentang Standar Akuntansi Pemerintahan.

[2] Undang-Undang Nomor 15 Tahun 2004 tentang Pemeriksaan Pengelolaan dan Tanggung Jawab Keuangan Negara.

[3] M.C. Suchman, "Managing Legitimacy: Strategic and Institutional Approaches," Academy of Management Review, vol. 20, no. (3), pp. 571-610, 1995.

[4] Peraturan Menteri Pendayagunaan Aparatur Negara dan Reformasi Birokrasi No. 20 Tahun 2013 Tentang Perubahan Lampiran.

[5] Peraturan Menteri Pendayagunaan Aparatur Negara dan Reformasi Birokrasi No. 25 Tahun 2012 Tentang Petunjuk Pelaksanaan Evaluasi Akuntabilitas Kinerja Instansi Pemerintah.

[6] A. Chairil, "Pengaruh Opini Audit terhadap Kinerja Pemerintah Daerah dengan Realisasi Pendapatan dan Belanja Daerah sebagai Pemediasi (Studi pada Pemerintah Provinsi di Indonesia Tahun 2010 sampai dengan Tahun 2014)," Simposium Nasional Akuntansi XIX. Lampung, 2016 . 